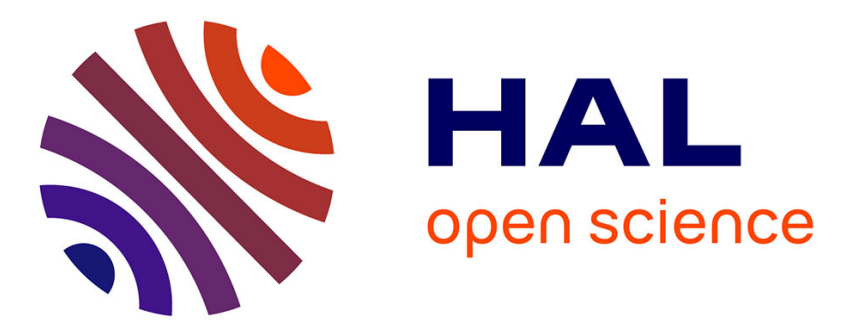

\title{
Scholars and poor communicators? Old Masters exhibitions as a scientific practice and communication activity for art museum curators
}

Pascal Ughetto

\section{To cite this version:}

Pascal Ughetto. Scholars and poor communicators? Old Masters exhibitions as a scientific practice and communication activity for art museum curators. Current Sociology, 2017, 65 (3), pp.376-394. 10.1177/0011392115617226 . halshs-01673854

\section{HAL Id: halshs-01673854 \\ https://shs.hal.science/halshs-01673854}

Submitted on 10 Jan 2018

HAL is a multi-disciplinary open access archive for the deposit and dissemination of scientific research documents, whether they are published or not. The documents may come from teaching and research institutions in France or abroad, or from public or private research centers.
L'archive ouverte pluridisciplinaire HAL, est destinée au dépôt et à la diffusion de documents scientifiques de niveau recherche, publiés ou non, émanant des établissements d'enseignement et de recherche français ou étrangers, des laboratoires publics ou privés. 
Scholars and poor

communicators? Old Masters

exhibitions as a scientific

practice and communication

\section{activity for art museum curators}

Current Sociology 2017, Vol. 65(3) 376-394 (C) The Author(s) 2015

Reprints and permissions: sagepub.co.uk/journalsPermissions.nav DOI: |0.1I77/00||392|I56|7226 journals.sagepub.com/home/csi

@SAGE

\title{
Pascal Ughetto
}

Université Paris-Est, LATTS, France

\begin{abstract}
Museum curators are rarely the subject of analysis as scientists. By contrast, there is a whole literature on their propensity to give priority to the scientific knowledge of collections over the effort to communicate with different audiences and make museums accessible. This article examines the Late Raphael exhibition at the Louvre (Paris) and draws on the exhibition texts (catalogues, artwork labels, wall texts) to explore the practical activity and preoccupations of the museum curators concerned: the exhibition is simultaneously material for the scientific demonstration of a thesis - part of a debate on the value of the artist's late works - and for communication aimed at both fellow specialists and the wider public. Communication is not distinct from scientific research and handled with less respect. The two are directly interwoven and communication represents a practical activity with its own difficulties.
\end{abstract}

\section{Keywords}

Communication, curator, museum, scholarship, scientific activity

For at least a century, museums have been the focus of conflicts over the definition of their role and the legitimate activity of their staff. Curators in particular have come under fire for their conception of the museum and their professional practices. They have been

\section{Corresponding author:}

Pascal Ughetto, Université Paris-Est, Laboratoire Techniques, Territoires et Sociétés, 5, Boulevard Descartes, Champs-sur-Marne, 77454 Marne-la-Vallée Cedex 2, France.

Email: pascal.ughetto@u-pem.fr 
and are still accused of being content to work in an ivory tower, remote from the interests of museum visitors and uninterested in making their knowledge accessible to laypeople (Bourdieu and Darbel, 1991 [1966]). Art museums and curators are not the only targets of such debates, and arguments about museological practices and about the connection between the purposes of the museum (e.g. curation of collections, research on those collections and efforts to make them interesting to audiences with varying levels of expertise) are to be found in every speciality. Nevertheless, art curators are more specifically exposed to these critiques, accused of expecting visitors to revere the works rather than helping them to understand them for themselves. The fear is that the meticulous emphasis on extending and documenting collections may take precedence over the development of explanatory materials for audiences of different kinds. The criticism comes from within the curatorship profession itself (representatives of science museums, ecomuseums, interpretation centres, museums of ethnography and even archaeology), but also from other professional communities, in particular those involved in pedagogical and communication activities (Kavanagh, 1991, 1994).

Museums are both places of science and public facilities open to visitors for cultural and recreational ends. Curators themselves are simultaneously scientists and employees whose role it is to attract visitors in different ways: arranging exhibition spaces, drafting explanatory texts. It is the connection between these two roles, the investment in the scientific aspect and in public communication, which generates polemics.

In this article, I move away from the traditional approach to this subject by focusing on the activity itself. The aim here is to explore what is the practical outcome, for art curators, of having to do scientific work on collections and, at the same time, to communicate with the public about them. The approach is to assume that it is not the case that curators focus exclusively on collections, possibly to the detriment of their concern for the public, but instead try to reconcile the two (Heinich and Pollak, 1996). What is different in this approach is that the existing literature tends to make claims about what curators do, what stances they adopt, rather than to record what they actually do in their work. Another difference lies in the careful attention to the importance that curators generally attribute to ensuring that their work is recognised as scientific. Taking the time to see what they mean by this, how they perceive it and how they adjust to it in their practices, means examining the nuances of their work, for example that the issue for them is not so much a rejection of the idea of museums as exhibition places for the public as their belief in the importance of the status of museums as places of scientific activity.

A crucial point is that curators do not do science at certain moments and public communication at others, but often both at the same time. This is particularly the case in the staging of temporary exhibitions. My intention here is to approach the exhibition from the perspective of the scientific instrument which it can also be. For curators, this means handling the simultaneous need to do science and to produce an event that is accessible to a lay audience, to make discoveries and communicate them to both the general public and their fellow scientists. In my analysis of this interwoven function, the subject of my study is the Late Raphael exhibition (Paris, Musée du Louvre, 11 October 2012-14 January 2013). My approach - set out later in this article - is to assess these aspects of the activity and the tensions they represent through texts of three kinds: the wall panels 
at the entrance to each section of the exhibition, the descriptive labels placed alongside each work and, finally, the catalogue.

\section{What curators do or what they should do?}

\section{A critique of curators' preference for scholarship}

A large proportion of studies that investigate museums and their staff is the work of authors who, closely or distantly associated with museum activity, adopt a would-be reflexive attitude to their institutions and their colleagues. They borrow instruments and concepts from the social sciences - history, sociology, anthropology, communication systems studies, etc. - in a way that never strays far from the formulation of judgements and recommendations. A whole academic field has formed, standing at the interface between analysis and prescription, called museum studies (Burcaw, 1997; Vergo, 1989). These writings serve to express personal or collective positions regarding the appropriate authority of experts over laypeople, the recognition of the skills of one or other possibly overlooked category of professionals, the division of prerogatives between one group and another, and so on.

Amongst these authors, some place in the mid-1980s the emergence of a definition propounded by certain museum actors, in particular the International Council of Museums, which broke with the idea of the museum as a temple to heritage and knowledge, where reverential audiences docilely absorb learning imposed by authority, but also the idea of curators as purportedly the sole repositories of knowledge about the objects and their correct interpretation (Hudson, 1998; Starn, 2005). In fact, reflection and debate on the role of the museum began much earlier, running right through the 20th century (DiMaggio, 1991). As a result, curators are unquestionably under scrutiny, suspected of being motivated by values that incline them to favour the works over the public, to exalt the former and despise the latter. They are believed to harbour a preference for the scholarly dimension over the public communication element.

Amongst others, Eilean Hooper-Greenhill claims that 'We need to consider the museum as a communicator' (Hooper-Greenhill, 2000: 12). In her view, the museum model to which curators cling practises a communication based on assumptions that make it purely a technical act: staff attend purely to questions such as what pictures to hang, how to arrange them, what texts to attach, without ever considering 'the social and cultural aspects of the process' (2000: 17). In this characterisation of museums and curators as largely uninterested in communicating accessibly with non-experts, the scientific aspect of the concerns of museums and curators is perceived and described as a problem. It is seen as simply reflecting the tastes and values prioritised by curators, imported to a lesser or greater degree from outside the work environment, for example from their original social class.

In reality, the scientific element receives little attention in writings of this kind. The priorities of curators are more postulated than observed. Ultimately we know little about how this scholarship is embodied in a working process, is given form in definitions of legitimate work, about the representations of the work on the art objects expected of curators in professional practices. Similarly, nothing is said about the actual practice of communication by curators. Exhibitions and the presentation of collections are not 
analysed as scientific work, but essentially as social choices hiding behind the purported objectivity of science (see e.g. Macdonald, 1998: 1).

\section{Reforms in recommended practices rather than an analysis of museum work}

The fact is that this is quite simply not the subject of this literature. It is activist literature with a more or less openly prescriptive purpose, focusing not on the work of curators but rather, on the basis of a certain experience in the field, on developing theories about what the museum should produce, for example in educational services or exhibition layout. The sociological approaches it borrows from place the emphasis on processes that restrict access to the museum for the least culturally and socially well-equipped (Bennett, 1995: Ch. 6; Bourdieu and Darbel, 1991 [1966]) or help to define the conditions for the assimilation of museum content.

What this literature seeks to promote is the importance of what in North America has come to be termed interpretation (Merriman and Brochu, 2006), in other words all the work that museums and their staff should do to make museums accessible to audiences who are not on the 'same level' as they are. Interpretation or mediation argues for greater effort to be put into communicating with the public about the meaning of museum objects, on the plurality of meanings, and therefore into producing much more information for the public.

All these factors brought the status of the collection as the cornerstone of the museum under fire, opposed by the view that its fundamental role should be pedagogical. Once again, this was less a matter of observation than a proposal for a new way of conceiving the museum, no longer as the privileged territory (jurisdiction) of professional prerogatives (Abbott, 1988), but as a space where curators should yield ground to other disciplines, in particular the educational profession.

In this context, curators were asked to see the exhibition as a system or medium of communication, an interface between a sender and a receiver (Davallon, 1999). As exhibition producers, they were expected to speak clearly to a non-expert public, to avoid writing obscure texts and imposing the value of the works by virtue of authority. Today, these expectations are reinforced by the identification of museums as public amenities and exhibitions as cultural products, subject to marketing tools.

\section{Art museum curators: A scientist's role}

In the museology manuals (Burcaw, 1997; Gob and Drouguet, 2003), this interpretation of the curator's role is presented as self-evident and necessary, whereas in fact it is still a battlefield. In reality, many misunderstandings and symbolic hierarchies remain in the ordinary working relations between curators and educationalists (Zolberg, 1986), as well as between curators themselves. However, what is still lacking is a precise examination of the nature of the work.

\section{A detour through the study of the nature of the work}

What do curators actually do, particularly in art museums? What do they claim to do? What meaning do they attribute to their working activities and what activities do they see as an integral part of good professional practice? 
Studies like those of Goodwin (1994) tell us that professionals mutually recognise each other and assign a value to their work at a very fine-grained scale of observation. It is here that the difference between professional categories and their debates about values and practices is to be found (Strauss et al., 1997). Acord confirms that we can understand the preparation of an exhibition by observing it as a practical activity in which the display choices are not 'an outcome of institutional structure or the values held by particular actors' (Acord, 2010: 449) but a constructive capacity to 'draw on environmental and semiotic resources in the production of explicit culture' (2010: 460). For sociologists therefore, close observation is needed, both of the activity and of the narratives that curators develop around it. If curators seem to prefer to talk more about the scientific component of their work than the communicative, it is perhaps not only because they wish to avoid tasks that they supposedly despise but also because science is connected with a whole set of meanings that profoundly structure the sense that they individually and collectively associate with the profession and with professional practices that have value.

Curators make strong claims for their scientific activity, not their scholarship, a word which they use less frequently. This is a discursive strategy to influence the social construction of their role, to establish distinctions between each other and in relation to other professions. It has the effect of conveying an image of themselves as disinterested actors and slides over their active role in the production of values recognised on the art market, despite their strong involvement in this field or in the social worlds of art (Becker, 1982; Bourdieu and Darbel, 1991 [1966]). However, the reference to the activity of studying collections also quite clearly reflects a set of meanings around which certain sections of the profession give sense to the work to be done and to legitimate practices.

Nevertheless, it is an activity largely neglected in the field of science studies. In fact, the focus of science studies in this domain is either the way in which museums handle science (for almost a century now it has been accepted that science should not be represented in museums in the same way as other subjects, and science museums have therefore undertaken to be places for ideas and innovation relating to display methods), or laboratory scientists working in domains such as physics, chemistry, the life sciences, but not in the history of art. Studies investigate laboratory life, explore what happens at the laboratory bench, the relations with objects and colleagues (Clarke and Fujimura, 1992; Knorr-Cetina, 1999; Latour and Woolgar, 1979); they may also look at the history of the studio as the working environment of painters (Alpers, 1998), but the idea of working as a scientist in the museum context is not considered. The sociology of science emphasises other ways of exploring museification or art history: showing how the history of artworks can potentially contribute to the sociology of science by 'multiplying mediations' (what varnish was used, who has owned the work, etc.) in order to contribute to the understanding of the value attributed to works (Latour, 1998); showing how the material installation influences the way a work is seen (Alpers, 1991) and employs narratives and produces meanings (Yanow, 1998); exploring 'how we inherit the past', in other words 'is it possible and legitimate to artificially create an appropriate way of keeping a "natural” system alive?' (Gagliardi et al., 2010).

Within science studies, the most useful contribution remains Star and Griesemer's paper on boundary objects, usually perceived as a classic text for its theoretical reach, but empirical in its use of the case of a museum as its demonstration material (Star and Griesemer, 1989). It looks at the question of scientific work as an activity of 
classification, the issue being how collaborations between amateurs and professionals form around it, and it thereby tells us about one aspect of the scientific activity taking place in museums. However, the emphasis needs to be widened to document the scope and forms of classification in other fields such as the arts. Moreover, scientific work is not restricted to classification. And all of this should be considered as a matter of professional conflicts between curators and other groups.

\section{Preparing exhibitions, a scientific activity in art history}

If the history of art can be spoken of as a scientific discipline, it owes much to the way in which the Prussian JJ Winckelmann (1717-1768) set out its principles in the History of the Art of Antiquity in 1764, and how his contemporaries saw in it the possibility of legitimate new ways of discussing the value of artworks, by contrast with the practices of amateur antiques collectors. The Frenchman AC Quatremère de Quincy (1755-1849) helped to translate elements of Winckelmann's doctrine into practice, by intervening in a controversy about the transfer to Paris of works seized in Italy by Napoleon's army. Quatremère cites Winckelmann as the man who showed that collecting should not consist in the acquisition of a disparate mass of objects deemed beautiful or curious: before him, he wrote, 'everything was without coherence, without order; nothing had been analysed, nothing compared' (Quatremère de Quincy, 1989 [1796]: 102); 'he was the first who, in classifying eras, brought history and monuments together and compared monuments between them, discovered sure characteristics' (1989 [1796]: 103). Classifying, ordering, comparing, similarly to the naturalists of the same era, thus emerge as being the foundation of a practice that seeks to know scientifically, to document, to analyse. Assessing value is part of the process of classifying and categorising, which entails the meticulous observation and comparison of characteristics. Working scientifically thus demands a process of juxtaposition. This task, he wrote, required 'uniting the materials that Rome provided' (1989 [1796]: 104).

This conclusion arose during a controversy about whether the value of artworks could be better assessed by bringing them together in museum collections or seeing them in situ, in their environment. In other words: what is the best possible arrangement, if we accept that an artist who worked in Rome lived in a world where he was surrounded by works from earlier eras, which had become part of the landscape? Is it the arrangement that maintains this embeddedness in the environment? Alternatively, given that the works have been extracted from their original environment, is it the arrangement that makes the museum a structure that creates the conditions for scientific study? From this perspective, the task of analysing works for the purpose of explaining their value by documenting the historical process required a certain spatial arrangement, perhaps a structure, at a time when museums were beginning to take the form that would come to dominate in the 19th century.

In fact, the organisers of the Louvre exhibition of the Napoleonic army's Italian seizures echoed Quatremère's argument: they 'emphasised that much of the value of the exhibition sprang from the fact that famous masters could be represented by significant numbers of their pictures hanging together instead of being widely dispersed, and that this would enable useful comparisons to be made'; 'juxtapositions were specially designed to throw light on stylistic contrasts' (Haskell, 2000: 33). 
What is referred to here is what we know as the exhibition. And indeed, in the years that followed, the success of museums would be confirmed by the invention of a new sociotechnical apparatus: the exhibition. Haskell has reconstructed their history and shown how, as much as an event that attracted crowds of visitors, the exhibition was also a framework for scientific production. For Haskell, the most crucial steps were taken in early 19th-century Britain, reflecting the aspiration to enable genuine and meticulous study of the works (Haskell, 2000: Ch. 3). The same era saw the invention of the catalogue, an object that would become a keystone of the scientific approach. Other innovations consisted in employing qualified experts to organise the exhibitions and staging exhibitions in order to settle disputes regarding attribution and authenticity.

\section{The Late Raphael exhibition}

\section{The exhibition as the scientific activity of curators}

The status of the collection in the purposes and practices of the curator's profession is crucial. When the relationship between curators and collections is explored in the scarce research that gives a glimpse of this activity, it is generally with a view to studying how collection pieces are incorporated into databases (Beltrame, 2012; Hemmings et al., 1997). Here, sociologists are essentially concerned with understanding how classification is done, through an active effort of categorisation that is in no way mechanical but instead requires, for the purpose of the technical operations, decisions about what has value and what does not, why a particular object warrants inclusion in one category or allocation to a different one, and so on.

Such studies give us an entry into the activity of curators, independently of the judgements usually made of them. Hemmings et al. write, for example:

The museum 'collection' constitutes the central reality and rationale of curatorial work. In their daily activities, curators work with 'the collection' in myriad, socially shared and socially legitimated ways. The work done includes such activities as accessioning, whereby objects come to be included in collections, and classified as being of a 'kind' within this collection; work involved in identifying and documenting a collection's items, including the hidden collection of objects, artefacts and texts not on display, and the work of display/exhibition making. (Hemmings et al., 1997: 150)

In their close study of the process of database construction, they describe what it means to incorporate items into the catalogue. In this way, they highlight the activity of generating inscriptions (Latour and Woolgar, 1979):

The inscriptions which are generated, be it in the catalogues, the cards accompanying displays, or the fields in databases they use, indicate not just the name of the object representative of its class but also provide an expert author-ised version of its status. That is, the act of examining and inscribing the object's status is an attribution of 'value'.... Deciding 'what kind of object it is', then, is a matter of providing a description which incorporates judgements that come under headings that may include 'provenance', 'uniqueness', 'rarity', 'representativeness' and 'thematic relevance' to the 'collection'. (Hemmings et al., 1997: 153-154) 
This is exactly the perspective I shall now adopt, though in this case less directly in relation to the cataloguing than to the exhibition, where I will indeed look at the inscriptions on the cards accompanying displays, in order to understand the objectives and methods of the scientific work.

\section{Raphael: A questionable exhibition?}

The exhibition studied was staged at the Louvre, from 11 October 2012 to 14 January 2013 (after the Prado Museum, Madrid, from 12 June to 16 September 2012), with the title Raphaël, les dernières années [Late Raphael]. The empirical material collected during this process is part of a longer term research project on the subject of the museum's opening up to the general public and its effects on the work of museum staff. One of the components of this research was to study the exhibition closely as a boundary object involving curators, educators and visitors (Ughetto, 2011). The exhibition is the object of potentially discordant interpretations about its purpose and the problem of knowing how to communicate effectively through its content. The material media of an exhibition (arrangement of works, accompanying texts, etc.) are not 'separate' from the scientific reasoning, they are its expression and essential foundation. This is because the scientific content shows itself through a narrative which is itself expressed through objects. As Hemmings and his colleagues again write with great accuracy:

The production of the exhibition is as much the production of a story as it is the production of an organised set of artefacts, and the communication of the manner in which they inform each other. The objects, the accompanying text, and the positioning of objects vis-à-vis others together tell the desired story. (Hemmings et al., 1997: 157)

The reactions to the Raphael exhibition tended to celebrate the exceptional nature of the paintings assembled, which the public rarely had the opportunity to admire outside the host museums. The relevance of the topic of Raphael's final years in Rome, as a specific entity, was not disputed. In its formation, however, the exhibition presented a problem: focusing on the great master figure Raphael, its content nevertheless included a significant number of works by his two main disciples and assistants in his studio, Giulio Romano and Gianfresco Penni. For the visitor, this raised the difficulty of knowing what to do with the information. The starting point for the study I will now undertake is the full page dedicated to the exhibition by Philippe Dagen on 2 November 2012 in Le Monde, one of France's leading dailies. A professor of art history at a Paris university, he regularly writes as a journalist about major exhibitions. His piece on Raphael went further than other newspapers by asking whether the makers of the exhibition had set themselves the right objective:

In dedicating an exhibition to this period, the Louvre, in this case in partnership with the Museo del Prado, had an excellent subject and the opportunity to give visitors the illusion of entering the artist's studio and understanding how it worked. However, that is not exactly what happens.

Most of the essential paintings and drawings are there, 75 in all ... so it is not an issue of loans. It is more that, while the notion of planned and collective production is central here, the exhibition curators, Paul Joannides and Tom Henry, persist with their questions on attribution. Is this really 
Raphael's own work, is the question constantly asked on the accompanying texts. Or just three quarters? What was begun by Romano or Penni and just slightly reworked by the master?

For Dagen, it is not very interesting for the non-specialist visitor and as a scientific question to try to distinguish the parts of a painting that come from the master's hand from those produced by his first and second assistants. The exhibition shows how Urbino-born Raffaello Sanzio acquired a reputation that brought him significant commissions from Julius II then Leo X: in Rome, Raphael attracted an explosion of commissions, raising the practical problem, for the first time in history, of having to produce masterworks on a very large scale. In terms of the studio model common amongst artists of the time where the master conceived the work and delegated the production of various parts to assistants, personally undertaking only the most characteristic elements - the novelty was that, because of the scale, Raphael was obliged to delegate the majority of production to his pupils. The question, therefore, is: to what extent does this nevertheless remain one of Raphael's works, easily identifiable at first glance as being in Raphael's style and technique? The choice of the exhibition's designers was to attribute (through archives and, above all, the study of style) the parts that are unquestionably attributable to each of his assistants, in order to show how Raphael divided the work and assigned it on the basis of the skills he knew each of them to possess.

Starting from this point, my study of the exhibition was based on the analysis of the texts associated with it. This entailed a close examination of the catalogue (in particular its main introductory chapter, written by Joannides and Henry) (Henry and Joannides, 2012), and the accompanying exhibit labels and explanatory wall texts, written by the curator of the Louvre, Vincent Delieuvin. All the exhibit labels and wall texts were compiled by the Louvre into a press pack, but I also studied them in situ, at the exhibition itself, with a particular focus on their location and the arrangement of the works. The public response was not part of the objective of the study, although I visited the exhibition three times, at periods of differing footfall, to observe visitor behaviour and the nature of their interest in the works and in the texts. Although semi-directive interviews were only a secondary component of the method, I was able to conduct an interview with the curator of the Louvre in charge of the project. The heads of the Louvre and Prado Paintings Departments instigated a plan for collaboration on the study and display of their collections, in which one curator from the Louvre (Vincent Delieuvin) and one from the Prado (Miguel Falomir) headed a project for an exhibition based around Raphael's late paintings held in the two museums' collections. Because of their workload, they approached two British academics to act as scientific curators. This exhibition was itself the culmination of the restoration, for the occasion, of certain paintings, which provided an opportunity for closer study (including the use of instruments such as scanners) through a collaboration between art restorers, technicians of all kinds, curators and academics, in a process that included dedicated study days. The model was not that of a 'blockbuster' event intended to attract large numbers of visitors, a model that prompts some curators to accuse colleagues who organise such exhibitions of lacking scientific legitimacy (at the same time, for example, in Paris, an exhibition on Impressionism and fashion was criticised by P Dagen for being no more than a pretext to pull in crowds attracted by the theme of Impressionism). Nor was it a touring exhibition staged for 
commercial ends, at the risk of damaging the works. Conversely, it was not of the kind that the Louvre calls an exposition-dossier - a themed exhibition - primarily understood by specialists. It occupied an intermediate ground between the two extremes.

\section{Communicating with experts and laypeople through the same texts}

\section{Material dimensions of the exhibition}

The exhibition was arranged in the standard layout of spaces for temporary exhibitions at the Louvre. The general size and architecture of the rooms is therefore a given, which the curators can do little to change. Whatever the event, the entrance wall outside the exhibition rooms displays a general introductory text, then in each of the main sections of the exhibition, there is a text placed on a wall painted in a colour that varies to mark divisions and progression. In fact, therefore, an exhibition is structured in the same way as a written text, with a plan and introductions, followed by development. This development takes the form of the works, their display layout and their accompanying texts. In part, this narrative is also constructed by the behaviour of visitors, who linger more over certain texts than over others.

The Raphael exhibition consisted of seven sections: (1) 'From Perugino to Michelangelo, the education of Raphael', (2) 'Raphael in Rome, the mature altarpieces', (3) 'The great Roman decorations', (4) 'The large Madonnas of maturity', (5) 'Giulio Romano, the pupil prodigy', (6) 'Gian Francesco Penni, a faithful assistant' and (7) 'Raphaël, master of the portrait'. The exhibition began $(1,2)$ with a historical narrative thread on Raphael himself to help visitors situate the Roman period within the painter's history, but immediately 'switched', with section 2 , to a thematic narrative, which continued until section 4. It is in these parts 2 to 4 that we see the efforts to attribute portions of the paintings between Raphael himself and his pupils, along with drawings, mostly by these pupils, showing how they handled the demands placed on them by Raphael. In the two succeeding sections, following section 4 where we saw how Romano, in his own style, handled the same subjects as Raphael in well-known paintings, the focus of the narrative shifted successively to Raphael himself and then his assistants. The final section returned to Raphael alone, with a thematic focus on his most famous portraits.

There were complex aspects to this way of organising the narrative, which one curator compared with another exhibition held in Paris at the same time: 'just as meticulous', in his view, this other exhibition seemed remarkable for its immediately comprehensible 'chaptering'. The remark suggests that, in this case, the commentator was not advancing the standard opposition between scientific ambition and accessibility, but instead comparing and contrasting the readability of two equally scientifically ambitious exhibitions.

\section{Who painted what, and what is the respective value of three artists?}

A big challenge of scientific analysis in art history is to ascribe a value to artists and their work. All the skill of professionals such as curators or indeed artwork restorers (Hénaut, 2006) lies in defining what the artist is doing, what he/she produces, in order the better 
to establish facts that facilitate decisions on value. For example, restorers who discover in the deeper layers of a Veronese painting that, underneath the red we have become used to, there was originally green, will argue over the description of this green ('stiff' [sic], 'beautiful'), in judgements that are only superficially aesthetically driven: ultimately, the primary aim is to know whether this was the type of green that Veronese used and therefore whether this part of the picture was painted by him or someone else.

The point is crucial when we compare what was written about Romano and Penni. The texts accompanying the exhibits show the scientific work on the study of styles. A significant proportion of their content seeks to describe each of the artist's works (e.g. the 'workmanship') in order to guide attribution but also to decide on artistic value. Certain texts only make rudimentary suggestions about the differences in value between the contributions by Raphael and his assistants: 'it is a work of somewhat disparate quality, with fine parts such as the faces of Jerome and Mary side-by-side with more sketchy parts, such as the landscape or the lion' [ $\left.1^{1}\right]$. Some also base attribution on knowledge of the themes or habits common in one painter or another: 'This drawing, with its strong contrast between shadow and light, is tricky to attribute. While some give it to Raphael, it is possible that it may instead be the work of Gian Francesco Penni' [45]. Many others, however, go further in the effort to found the value of artworks and artists in the analysis of artistic production.

This comparison brings out a gradation between the three artists concerned. In this ranking, Raphael is credited with a technical mastery greater than that of the two others, which he brings to a handling of the subjects that guarantees the subtlety and richness of the depiction, for examples of the feelings of the protagonists. The exhibition presents Romano as an artist who is clearly not the equal of the master in the period of his life when he is an assistant, but in whom we can already see the first signs of a future artist of great value, although ultimately not as great as Raphael. His technique is described as less subtle than the master's. In particular, he practises 'simplifications of workmanship':

The workmanship is of fine quality, but lacks the subtle contours of the original painted by his master. [49]

Of disputed attribution, the painting shows a slightly dry workmanship, particularly in the handling of the complexions and draperies, which suggests that its author is Giulio Romano, whose temperament is apparent in the numerous references to antiquity. [53]

This is associated both with inferior skill and a more abrupt and impatient artistic temperament:

On the other hand, the highly refined execution, rivalling in its meticulousness that of the Flemish school, would seem to be by Giulio Romano, who fails to give his protagonists as much psychological force as his master, or his figures as much relief. [68]

While the liveliness of expression and the delicate workmanship are attractive, the construction of the relations between the figures lacks a little coherence and is less convincing than in the later Madone Herz. [61] 
The part of the exhibition specifically dedicated to Romano seeks to support this line of interpretation of his value and the identification of his particular style. The goal is to help identify his own specific interventions in Raphael's studio and, conversely, to decide what comes from the hand of the master himself.

Finally, at the bottom of the hierarchy, Penni is described as not devoid of talent, but lacking the technical mastery of Romano: imprecision in contours [101, 60], a cold palette [71], fixed expressions [55, 56], etc.

Here, the imprecision of the contours, like the less skillful use of washes and white highlights, reveal[s] the hand of the Fattore, Gian Francesco Penni. [101]

The calm cadence of the action and the close workmanship would tend to suggest Penni's hand, as do certain imprecisions in the coherence of the background architecture and the anatomy of the protagonists. [60]

Nonetheless, it [the composition] differs in its cooler palette, a slightly frozen expression and physiognomies that may be attributed to Penni. [71]

The meticulous workmanship and delicate, but somewhat lifeless, expression resemble certain details of the Madonna of the Diadem, suggesting the hand of Penni. [55]

This Nativity could be one of the first of the solo paintings by the young artist, who still lacks narrative liveliness and simplifies the form of the draperies, though not without elegance. [56]

His interventions can thus be identified by a style that is not without interest, but a more laborious technique. The conclusion is therefore that Raphael employed him for a fairly limited part of the work, the modelli, i.e. the most developed drawings preceding the painting.

\section{Revisiting a controversy on the value of the master's late works}

Attribution is a central issue of the exhibition. However, it emerges only surreptitiously. It reveals itself only in a message to the visitor that emerges in the course of the exhibition, somewhat like Easter eggs hidden in a garden.

In the labels, first of all:

The simplification of certain shapes, in particular the contours, has inevitably raised doubts about the author of this piece, which constitutes a good example of the problems of attribution in Raphael's late drawings. [95]

While the workmanship is refined, certain weaknesses in the handling of the anatomy - in particular the hands and feet - inevitably raise doubts about its authorship, with historians divided between a hasty sketch by the master or a faithful imitation by his most brilliant pupil [i.e. Romano]. [17]

However, the precise meaning of these remarks is to be found in one of the exhibition panels. This explanation is not present in the very first panel, which opens the exhibition. 
Here, the strength of the Raphael exhibition is attributed to its having brought together 'the majority of his masterpieces', while the presence of work by his pupils primarily provides an additional point of interest ('The personality of his assistants is also revealed'). On the other hand, the fifth of the eight wall panels, 'The large Madonnas of the mature period', halfway through the exhibition, delivers the key to the mystery. The panel explains that the painter, although having dedicated himself in the Roman period 'to the design of great pictorial decorations and architectural projects', 'never abandoned the execution of paintings of private devotion representing the Virgin and Child'. These creations even achieve a virtuosity ('expression of grace and beauty', 'great variety of expressions') emphasised by the writers. 'These works were celebrated from their creation and throughout subsequent centuries'; however:

From the 19th century onwards, however, art historians have expressed certain reservations about the quality of the execution, without rejecting Raphael's role as designer. In bringing these paintings together for the first time, it is finally possible to compare their workmanship and better define the ultimate style of the Urbino master and his young assistants.

Here at last we see the purpose explicitly stated. It is the essence of the exhibition's scientific objective: to re-examine a controversy that dates back to the 19th century and has never been resolved. Or even a controversy that took shape during Raphael's lifetime: in the catalogue's main essay, Tom Henry and Paul Joannides explain that Raphael was accused by his rivals - denied his access to papal patronage - of producing work of mediocre quality in the parts delegated to his assistants. According to the authors, this was a period of re-evaluation in pictorial art under the influence of patrons and collectors, and also a time when artists such as Da Vinci, Michelangelo and Raphael were much hyped: patrons wanted works from the hand of the master, to the point of fetishising individual execution. Henry and Joannides maintain that if the artist's late works have been 'little understood' (Henry and Joannides, 2012: 17), it is because they raise problems of chronology, are of bewildering diversity and were produced by several hands. The exhibition therefore seeks to provide a chronology, to explain the stylistic diversity and to study the role of the studio in the conception and production of the works. In the absence of archives or commission contracts specifying the practical conditions of production, the authors essentially base their approach on a visual analysis of the works (2012: 18). In the history of painting, certain forms of scientific work are very close to a social history of art, seeking to reposition the works within the conditions of their production. Others, as in this case, seek more to attribute and interpret the works by bringing together the elements that can be used to achieve some degree of certainty as to their authorship - in which case they may draw for evidence on accounting documents or contracts exhumed from the archives - and/or by reconstructing the material production of the work: in this case, instruments such as scanners may be used to detect traces such as reworkings or 'overpaintings' (corrections by the artist of initial versions), or to compare initial sketches and drawings, drawings transferred to the canvas (modelli) and the definitive painting. Here, the task is also to observe the style of the painting's composition or detail (gestures of the figures, any disproportions between them, colour palette, etc.) in order to recognise an artist's habits and consolidate an attribution. 
So since scientific judgement on the value of the late Madonnas as productions has encountered an obstacle that is difficult to move, the aim was to exploit the opportunity afforded by the presence of these paintings in one place to gain greater understanding of the way the work was actually divided between Raphael and his two assistants, and thereby to observe the works in a more informed manner and ultimately decide to what extent these works remain Raphael's, and therefore of inestimable artistic value. The panel in question, halfway through the exhibition, introduced visitors to a section where they could primarily see these famous Madonnas, but also Romano's attempts to reproduce them in his style or draw inspiration from them. The layout permitted comparisons that made it apparent that Raphael's workmanship is more flexible, less stiff, his palette more subtle, etc.

The powerful handling of shadow and light gives a sculptural power to the drapery that tenderly enfolds the Mother and her Son. [18]

Its workmanship is both meticulous and gentle: the long blonde hairs painted one by one, the complexion subtly raised with whites and pinks, and the transparent eyes that give life to the expression. [77]

Here, the subtlety of the shadows, contoured by the washes that play with the margins of the paper, indicates the intervention of the master. [100]

The room behind, which explored the presentation of Giulio Romano as the more daring and talented of the two assistants, though never able to equal his master, acted as a digression before the return to the main argument concerning the consolidation of a scientific judgement on the value of Raphael's late works.

A visitor must therefore remain fairly concentrated or be something of an expert to follow this narrative thread. Less attentive visitors would tend to be content with a more simple narrative. Although they reproduced the main terms of the exhibition's scientific objectives, the explanatory panels in fact told a second story of the following kind: visitor, you are here to experience an exceptional gathering of major works by a great master like Raphael; in addition, you will also be able to appreciate a display that extends to works by his pupils; among the most important pictures are Madonnas; you should also know that this exhibition enables specialists to learn more about Raphael's late style.

The construction of the narrative is largely attributable to Vincent Delieuvin, reflecting the interplay between his own conception of the importance of the exhibition content and the method of display, debates with the other organisers and the resolution of the material constraints. Delieuvin and Falomir - the curators from the Louvre and the Prado - wanted an exhibition that would structure the works according to major themes, whereas the two British scientific curators wanted 'hanging by attribution' (i.e. consecutive hanging of all the paintings attributed to a single artist), and considered the drawings to be necessary, whereas the other two saw them as superfluous. Delieuvin also had to manage the difference in spatial layout between the Louvre and the Prado: little adjustment could be made to the successive areas, the ceiling heights were limited, which ultimately explains the existence of an introductory section only to be found in the Paris 
exhibition. 'Our display space is not great. For example, the exhibition opened into a small room, with a low ceiling. And there was I coming along with great big pictures, 4 metres high or more, and I couldn't put them in there' (Interview with Delieuvin, 4 July 2013). The solution chosen was therefore to include an introduction, which Delieuvin also felt was justified for visitors. The scientific curators did not agree: 'I had to fight. I thought that it was the best solution for the public.' There was also a 'Madonna of the Candelabra' which was located in the section for large altarpieces 'although that picture's not [an] altarpiece'. However, the scientific curators absolutely insisted that it should be seen near a 'Madonna of the Fish'. And, 'what finally convinced me was that I had no pictures to put on that enormous wall'. Putting nothing there would have 'looked horrible', and the display designer managed to convince Delieuvin. However, for the latter, it remained a problem of narrative, evidenced by the fact that each time he led a guided tour, he never managed to come up with anything but platitudes about that Madonna.

Another factor to take into account was the negotiation of the loans: if a museum refused to lend a painting, this could prevent the curator from developing the section of the narrative expressed in a particular room.

\section{Discussion and conclusion}

An in-depth ethnography of the collective task of producing an exhibition (e.g. Macdonald, 2002) would be needed to complete what here constitutes primarily a set of waymarks for a future research programme. Nevertheless, studying the exhibition through these texts helps to suggest that the acts of scientific demonstration and communication are embodied in the same material elements - displays, writings, etc. - which constitutes a practical problem that is not easy to solve. What we see here is a reality about the communication of exhibition content which proves richer in professional practices and dilemmas than a simple opposition between curators supposedly unable or unwilling to make themselves accessible, and educators who, for their part, wish to do so and possess the necessary skills. It is not the case that the communication component is separate from the scientific research and handled with less respect by curators for whom scholarly motives take priority over making themselves understood. In reality, the difficulties faced by the system of communication lie in the degree of communicability of the controversies between scientists.

Behind the analysis of the practical difficulties encountered, the purpose of this study is to take a different approach to the debate, which casts the supposed inclination of curators to neglect communication in favour of scholarly concerns. This sheds new light on the debates about legitimate professional practices between museum practitioners. Museums appear above all as a locus of conflicts between groups of actors who denounce each other about the objectives they are purported to pursue, but who, in fact, are not sufficiently clear about the professional foundations of their diverging views on the purposes of the institution. These foundations lie in the work, the work they consider useful and the work they do on a day-to-day basis.

Work matters: for much research in science studies, this statement reflects the concern to account for the ordinary and material production of science in laboratories, and therefore includes the work of scientists. The history of the sciences is not only one of successful 
'discoveries', but also of what is done, successfully or otherwise, to produce scientific facts. Ultimately, it is an activity that is as much about the interplay of human and nonhuman agents and the consolidation of networks (Latour, 1987) (in this case, walls, paintings measuring four metres, scientific curators ...) as about the simple relation to the scientific object. In this perspective, the contribution of this article is in its focus on a kind of scientist who has received little attention, the museum curator, and on professional practices of an interesting specificity and complexity: especially, what it means to design exhibitions through materials and arrangements that provide little latitude to distinguish between communicating with peers and communicating with a non-specialist audience.

However, as far as this activity of communication by curators is concerned, the ambiguity inherent in the activity, with its multiple recipients, has led to controversy regarding the legitimacy of the professional positions. Different professional categories of museum staff have, for many decades, been in conflict regarding the right way to communicate the content of exhibitions, who should be involved, and who should dominate the process of creating the messages conveyed. From this perspective, it is now important to know what museum curators actually do, this time in the sense of understanding them as truly at work. Examining the activity of curators is not only methodologically the right way to understand the science of art history; it also needs to be taken into account that they work within organised employment structures, amidst professional conflicts within institutions, and that, as employees, they are accountable to employers or sponsoring authorities.

The exhibition studied, like all other exhibitions today, was the outcome of coordination between specialised practitioners. However, these collaborations displace rather than nullify the practical difficulty that curators must resolve in communicating on their scientific objectives - in this case, settling a controversy on the value of Raphael's late works - and in reconciling this with the social expectations that require them not to express themselves as if they were speaking solely to their peers.

\section{Acknowledgements}

I would like to thank the reviewers most sincerely for their very acute and constructive comments. Any failings in this article naturally remain my responsibility.

\section{Funding}

This research received no specific grant from any funding agency in the public, commercial, or not-for-profit sectors.

\section{Note}

1. The figures in square brackets are the references of the works in the catalogue. Source: Exhibition labels, reproduced in their entirety in the media pack. The original texts only exist in French, and these are translations.

\section{References}

Abbott A (1988) The System of Professions. Chicago: The University of Chicago Press.

Acord SK (2010) Beyond the head: The practical work of curating contemporary art. Qualitative Sociology 33(4): 447-467. 
Alpers S (1991) The museum as a way of seeing. In: Karp I and Lavine SD (eds) Exhibiting Cultures: The Poetics and Politics of Museum Display. Washington, DC: Smithsonian Institute Press, pp. 25-32.

Alpers S (1998) The studio, the laboratory, and the vexations of art. In: Jones CA and Gallison P (eds) Picturing Science, Producing Art. Abingdon: Routledge, pp. 401-417.

Becker HS (1982) Art Worlds. Berkeley and Los Angeles: University of California Press.

Beltrame TN (2012) Un travail de Pénélope au musée. Décomposer and recomposer une base de données. Revue d'Anthropologie des Connaissances 6(1): 217-237.

Bennett T (1995) The Birth of Museum: History, Theory, Politics. London: Routledge.

Bourdieu P and Darbel A (with Schnapper D) (1991 [1966]) The Love of Art: European Art Museums and their Public (transl.). Cambridge: Polity Press.

Burcaw GE (1997) Introduction to Museum Work, 3rd edn.Walnut Creek, CA: Altamira.

Clarke AE and Fujimura JH (1992) The Right Tools for the Job. Princeton, NJ: Princeton University Press.

Davallon J (1999) L'Exposition à l'œuvre. Stratégies de communication and médiation symbolique. Paris: L'Harmattan.

DiMaggio P (1991) Constructing an organizational field as a professional project: U.S. art museums, 1920-1940. In: Powell WW and DiMaggio PJ (eds) The New Institutionalism in Organizational Analysis. Chicago: The University of Chicago Press, pp. 267-292.

Gagliardi P, Latour B and Memelsdorff (eds) (2010) Coping with the Past: Creative Perspectives on Conservation and Restoration. Florence: Leo S. Olschi.

Gob A and Drouguet N (2003) La Muséologie: Histoire, développements, enjeux actuels. Paris: Armand Colin.

Goodwin C (1994) Professional vision. American Anthropologist 96(3): 606-633.

Haskell F (2000) The Ephemeral Museum: Old Master Paintings and the rise of the Art Exhibition. New Haven, CT: Yale University Press.

Heinich N and Pollak M (1996) From museum curator to exhibition auteur: Inventing a singular position. In: Greenberg R, Ferguson B and Nairne S (eds) Thinking about Exhibitions. London: Routledge, pp. 231-250.

Hemmings T, Randall D, Francis D et al. (1997) Situated knowledge and the virtual science and industry museum: Problems in the socio-technical interface. Archives and Museum Informatics 11: 147-167.

Hénaut L (2006) Ce que les controverses nous apprennent sur l'activité de restauration des peintures au musée du Louvre. In: Gaudez F (ed.) Sociologie des arts, sociologie des sciences. Paris: L'Harmattan, pp. 195-210.

Henry T and Joannides P (eds) (2012) Late Raphael. London: Thames and Hudson.

Hooper-Greenhill E (2000) Changing values in the art museum: Rethinking communication and learning. International Journal of Heritage Studies 6(1): 9-31.

Hudson K (1998) The museum refuses to stand still. Museum International 50(1): 43-50.

Kavanagh G (ed.) (1991) The Museums Profession: Internal and External Relations. Leicester: Leicester University Press.

Kavanagh G (ed.) (1994) Museum Provision and Professionalism. London and New York: Routledge.

Knorr-Cetina K (1999) Epistemic Cultures. Cambridge, MA: Harvard University Press.

Latour B (1987) Science in Action. Cambridge, MA: Harvard University Press.

Latour B (1998) How to be iconophilic in art, science, and religion. In: Jones CA and Gallison P (eds) Picturing Science, Producing Art. Abingdon: Routledge, pp. 418-440.

Latour B and Woolgar S (1979) Laboratory Life: The Construction of Scientific Facts. Princeton, NJ: Princeton University Press. 
Macdonald S (ed.) (1998) The Politics of Display: Museums, Science, Culture. London: Routledge. Macdonald S (2002) Behind the Scenes at the Science Museum. Oxford: Berg.

Merriman T and Brochu L (2006) The History of Interpretation in the United States. Fort Collins, CO: The National Association for Interpretation.

Quatremère de Quincy AC (1989 [1796]) Lettres à Miranda sur le déplacement des monuments de l'art de l'Italie. Paris: Macula.

Star SL and Griesemer JR (1989) Institutional ecology, 'Translations' and boundary objects: Amateurs and professionals in Berkeley's Museum of Vertebrate Zoology, 1907-39. Social Studies of Science 19(3): 387-420.

Starn R (2005) A historian's brief guide to new museum studies. The American Historical Review 110(1): 68-98.

Strauss AL, Fagerhaugh S, Suczek B and Wiener C (1997) Social Organization of Medical Work. New Brunswick, NJ: Transaction Publishers.

Ughetto P (2011) Exposer un maitre ancien. Temps et histoire de l'art dans un dispositif d'exposition. Temporalités 14. Available at: temporalites.revues.org/1891.

Vergo P (1989) The New Museology. London: Reaktion Books.

Yanow D (1998) Space stories: Studying museum buildings as organizational spaces while reflecting on interpretative methods and their narration. Journal of Management Inquiry 7(3): 215-239.

Zolberg V (1986) Tensions of mission in American art museums. In: DiMaggio PJ (ed.) Nonprofit Enterprise in the Arts: Studies in Mission and Constraint. Oxford: Oxford University Press, pp. 184-198.

\section{Author biography}

Pascal Ughetto is a professor of sociology at the Université Paris-Est Marne-la-Vallée (France). As a member of the Laboratoire Techniques, Territoires et Sociétés (LATTS), his main research fields deal with the transformations of work since the 1980s, especially in the service activities, and their relations to changes in strategies, management tools and organisation. Museums, social housing organisations, hospitals and public administrations are amongst the sectors where he conducts fieldwork. On museums, he is the author, with O Join-Lambert, Y Lochard and M Raveyre, of 'Le musée pour tous: enjeux professionnels d'une politique publique', in T Le Bianic and A Vion (eds) Action publique et légitimité professionnelle (2008).

\section{Résumé}

Les activités scientifiques des conservateurs de musée sont rarement étudiées. Il existe en revanche un ensemble d'articles sur leur tendance à privilégier la connaissance scientifique des collections afin de pouvoir communiquer avec leurs différents publics et de faciliter l'accès aux musées. Cet article analyse les textes (catalogues, légendes des œuvres, textes muraux, etc.) de l'exposition « Raphaël, les dernières années », organisée au Louvre à Paris, pour mettre en évidence les activités pratiques et les préoccupations des conservateurs de musée. Cette exposition est un support à une démonstration scientifique en faveur d'une thèse sur la valeur des dernières œuvres de l'artiste et une présentation destinée à des pairs et à un public plus large. Cette communication s'apparente en grande partie à une recherche scientifique faisant preuve d'une moindre rigueur. L'imbrication des deux discours soulève alors un certain nombre de difficultés dans la mise en œuvre pratique de la communication. 


\section{Mots-clés}

Musée, activités scientifiques, bourses d'études, communication, conservateur

\section{Resumen}

Los curadores del museo rara vez son objeto de análisis en tanto científicos. Por el contrario, hay toda una literatura sobre su propensión a dar prioridad al conocimiento científico de las colecciones sobre el esfuerzo para comunicarse con diferentes audiencias y hacer accesibles a los museos. Este artículo examina la exposición del Rafael tardío en el Museo del Louvre en París y se basa en los textos expositivos (catálogos, etiquetas de las ilustraciones, textos de pared) para explorar la actividad práctica y las preocupaciones de los curadores de museos en cuestión: la exposición es a la vez el material para la demostración científica de una tesis - parte de un debate sobre el valor de las obras tardías del artista - y para la comunicación dirigida tanto a colegas de los especialistas y al público en general. La comunicación no es distinta de la investigación científica y es tratada con menos respeto. Ambos se entrelazan directamente y la comunicación representa una actividad práctica con sus propias dificultades.

\section{Palabras clave}

Museos, actividad científica, academia, comunicación, curador 